Original Scientific Article

\title{
DEVELOPMENTAL CHANGES OF LYMPHOID TISSUE IN THE HARDERIAN GLAND OF LAYING HENS
}

\author{
Pamela Bejdić ${ }^{1}$, Rizah Avdić ${ }^{1}$, Ljiljana Amidžić ${ }^{2}$ Velida Ćutahija ${ }^{1}$, \\ Faruk Tandir ${ }^{1}$, Nedžad Hadžiomerović ${ }^{1}$ \\ ${ }^{1}$ Department of Anatomy and Histology with Embriology, Veterinary Faculty, \\ University of Sarajevo, Bosnia and Herzegovina \\ ${ }^{2}$ Department of Pathology, Clinical Center, University of Banja Luka, \\ Bosnia and Herzegovina
}

Received 2 December 2013; Received in revised form 5 February 2014; Accepted 13 February 2013

\begin{abstract}
The Harderian gland of 110 laying hens was histologically investigated from the time of hatching to the period of 10 months of age. Tissue sections were stained with haematoxylin and eosin, periodic acid-schiff (PAS) and methyl green-pyronin technique. The research shows that lymphoid tissue is colonised by three types of cells: heterophils, lymphocytes and plasma cells. The number of these cells is directly dependent on the bird's age. During the lifetime of the hens there gradually comes a shift in the dominance of these three cell types. Lymphoid nodules are detected only in 40-day-old chickens, while later in adult birds the Harderian gland is the organ which contains the largest number of mature plasma cells. Some plasma cells contain Russell bodies with different size and shape.
\end{abstract}

Key words: Harderian gland, lymphoid tissue, development

\section{INTRODUCTION}

The Harderian gland in domestic birds lies behind the eyeball in the ventral and postero-medial part of the orbit $(10,22)$. Histologically, the gland was described as a compound tubulo-acinar organ covered by a thin connective tissue capsule $(1,8$, $12,17,23)$. In domestic birds this gland is much larger than the lacrimal gland and represents a major source of tears $(5,6,16)$. But, in addition to its exocrine role, the gland is also a secondary immune organ and represents an important part of the immune barrier CALT - Conjunctiva associated lymphoid tissue $(6,9,13-16)$.

Different researchers have reported that in domestic birds the interstitium of the gland is colonized by a large number of lymphoid cells $(2,3$,

Corresponding author: Pamela Bejdić, MSc

E-mail address: pamela.bejdic@hotmail.com

Present address: Department of Anatomy and Histology with Embryology,

Veterinary Faculty, University of Sarajevo, Zmaja od Bosne 90

71000 Sarajevo,Bosnia and Hercegovina

Tel. +38733655922

Copyright: (C) 2014 Bejdic P. This is an open-access article published under the terms of the Creative Commons Attribution License which permits unrestricted use, distribution, and reproduction in any medium, provided the original author and source are credited.

Competing Interests: The authors have declared that no competing

interests exist.

Available Online First: 18 February 2014

http://dx.doi.org/10.14432/j.macvetrev.2014.02.009
$4,7,11,18)$. Among them, a large number of plasma cells were recorded in adult birds $(2,15,19-23)$. Immunohistochemical investigations showed that these are $\operatorname{IgA}, \operatorname{IgM}$ and $\operatorname{IgG}$ containing plasma cells $(9,13,14)$. Recent findings indicate that in chicken, the lymphoid tissue of the gland is organized in two histologically different compartments, the head and the body (14).

However, relatively little information is available regarding to changes in distribution of lymphoid cells in the Harderian gland of laying hens during the different ages. Thus, the aim of this investigation was to determine the number of plasma cells and the distribution of lymphoid cells in the Harderian gland of laying hens, from the time of hatching to the period of 10 months of age. Through this investigation we will explain the process of glandular transformation into the secondary immune organ. This paper will provide valuable information for anatomist, immunologist and pathologist researchers.

\section{MATERIAL AND METHODS}

The research was conducted on 110 healthy laying hens (Lohmann Brown strain). The morphological characteristics and development of the lymphoid 
tissue of the Harderian gland was determined by light microscope examination of glands taken from the chickens aged between 1, 2, 3, 5, 7, 20 and 40 days and later adult hens, aged between 4, 5, 7 and 10 months. Each age group consisted of 10 birds. All birds were hatched and later reared on the commercial hen farm Agreks, Donji Žabari.

From the day of hatching until 18 weeks (wk) of age, the birds were reared on the floor in deep litter system. At 18 wk of age hens were removed and placed into the standard laying cages ( 5 birds in one cage). The diets were provided as follows: commercial chick starter from 0 to 6 wk of age, grower from 16 to $21 \mathrm{wk}$, and layer's mash from 21 wk until the end of the experiment. Water was available ad libitum for all birds. The photoperiod and ambient temperature were automatically controlled in accordance with recommendations for this strain. When birds reached certain age, ten of them (from each age group) were randomly collected and transported to the Department of Anatomy with Histology end Embryology, Veterinary Faculty in Sarajevo where they were decapitated in accordance with the law.

By careful dissection the Harderian gland was removed and fixed in $10 \%$ buffered formalin. The whole organ was embedded in paraffin blocks and cut into serial sections of $4 \mu \mathrm{m}$ thickness. Tissue sections were stained with haematoxylin and eosin for general histological examination, periodic acidshiff(PAS) for detection of carbohydrates and methyl green-pyronin for a detection of plasma cells (Sigma Aldrich). All samples were analysed under the light microscope Olympus UC 30 equipped with a digital

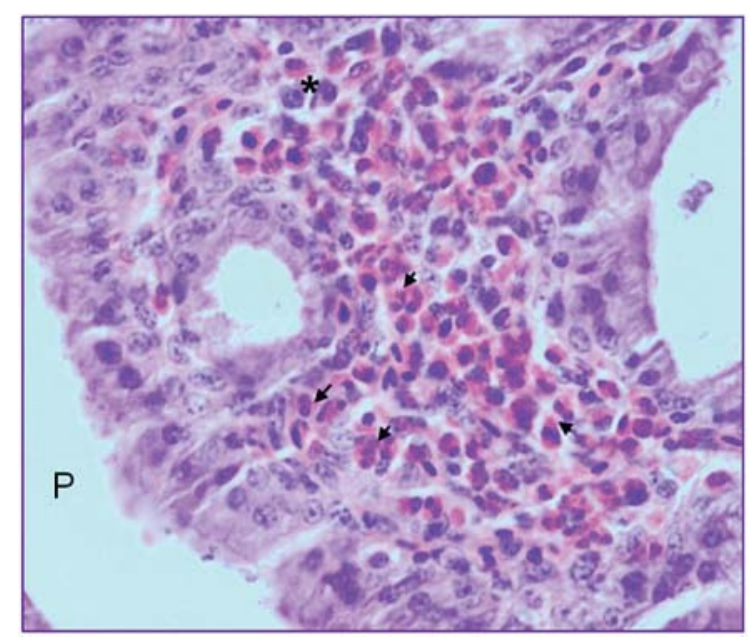

Figure 1. Large number of heterophils $(\rightarrow)$ and quite few lymphocytes and plasma cells $\left(^{*}\right)$ are present in the subepithelial region of the primary duct $(\mathrm{P})$ of the Harderian gland in a 7-day-old chick. (H\&E, 400X) camera. In the sections stained with methyl green pyronin technique, the number of plasma cells was counted in ten randomly chosen microscopic fields of standard size $(55 \times 55 \mu \mathrm{m})$. The average number of plasma cells was later tested by a statistical method of correlation (MS Excell) in relationship with birds ages. Correlation coefficients between studied traits were estimated at the level of significance $\mathrm{P}<0,05$. Also, on all slides stained with periodic acid-shiff we examined the presence, shape and histochemical reaction of Russell bodies.

\section{RESULTS}

The Harderian gland is situated just behind the eyeball where it extends from the medial margin of the orbit to the place where $n$. opticus penetrates the eyeball. It is a compound tubulo-acinar gland covered by a thin connective tissue capsule from which the fine separates, that also divides the parenchyma of the gland into lobules of unequal size (Fig. 3). Blood vessels and nerve fibers pass through the capsule and its septa. Within each lobule it is easy to distinguish the epithelium of the acini and ducts, and the subepithelialy situated lymphoid tissue.

In birds of all ages the lymphoid tissue is colonised by three types of lymphoid cells: heterophils, lymphocytes and plasma cells. These cells are diffusely scattered and occupy mostly the central part of the lobules of the gland, between the primary and secondary ducts, while a far smaller number of them is situated at the periphery, between the acini of the gland. The number of lymphoid cells

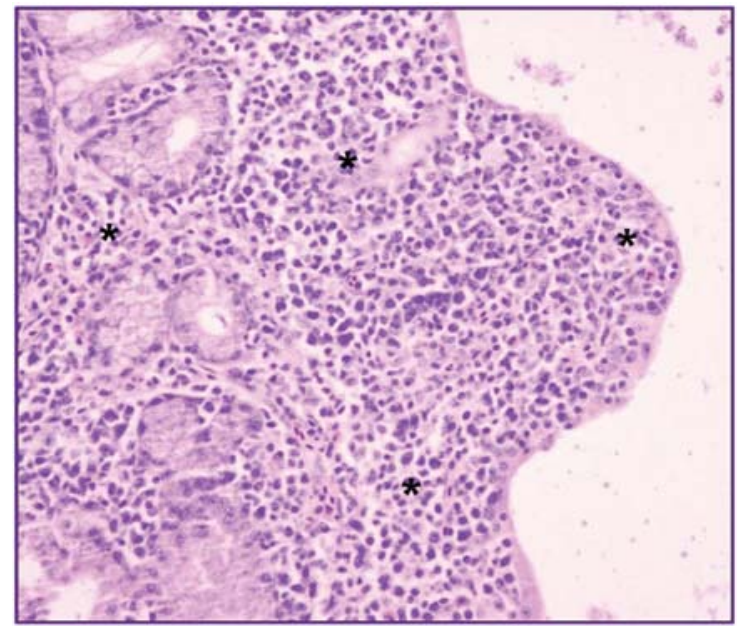

Figure 2. Interstitium of the gland in a 20-day-old chick is infiltrated by large number of lymphocytes $\left(^{*}\right)$. (H\&E, 200X) 
is directly dependent on the bird's age. From the time of hatching to the period of 10 months of age (Fig. 7) there gradually comes a shift in the dominance of these three cell types.

In the first 7 days after hatching, the interstitium of the gland is colonized by large number of heterophil granulocytes (Fig. 1). Only a few lymphocytes and plasma cells are present among them. The first changes inside the lymphoid tissue come in the period between 7 and 20 days. In fact, in 20-day-old chickens the interstitium of the gland is infiltrated by a large number of lymphocytes (Fig. 2).

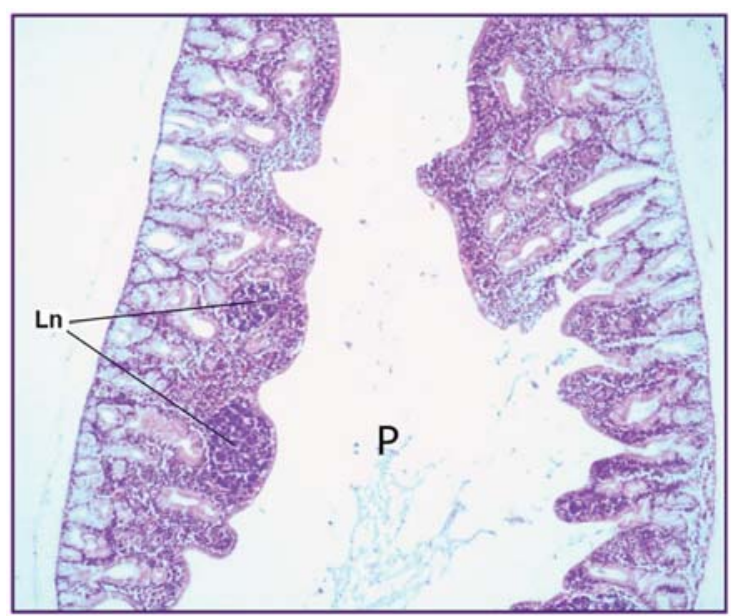

Figure 3. Two large lymphoid nodules ( $\mathrm{Ln}$ ) are visible in subepithelial region of the primary $(\mathrm{P})$ duct in a 40-dayold chick. (H\&E, 100X)

The number of heterophils in this age period is much reduced and there are also some mature plasma cells. Later, in 40-day-old chickens the typical lymphoid nodules (Fig. 3) are also present. Most of them are bounded by a thin connective tissue capsule and they have well defined outer mantle

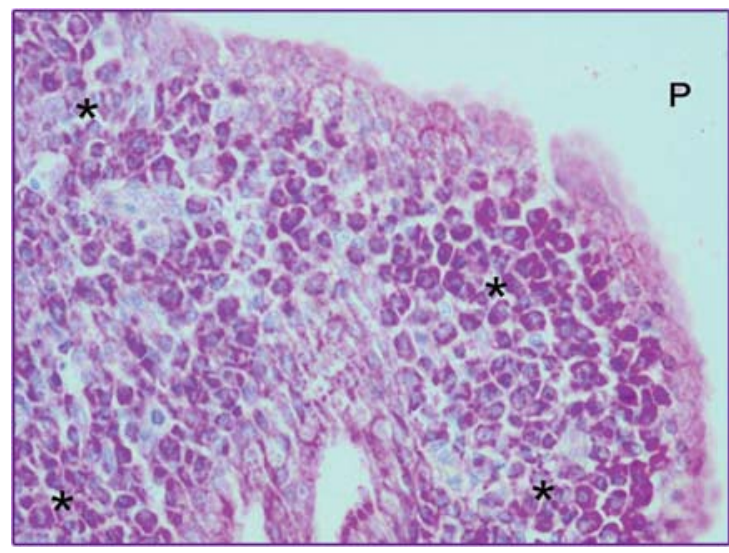

Figure 5. Interstitium of the gland in 7 month old laying hens is colonized by large number of mature plasma cells $(*)$ (Methyl green-Pyronin, 400X) zone and inner germinal center. Lymphoid nodules are mostly situated in the subepithelial region of the primary ducts, through its entire length, from head to the body of the gland. Outside of them, the stroma contains many mature plasma cells, groups of lymphocytes, and some heterophils. The number of plasma cells continuously increases during the age periods. In hens of 4 months of age and all older birds, plasma cells are so numerous that they represent a dominant population (Figs. 4 and 5). In adult birds we noticed that plasma cells often represent $90 \%$ of cells in one microscopic field.

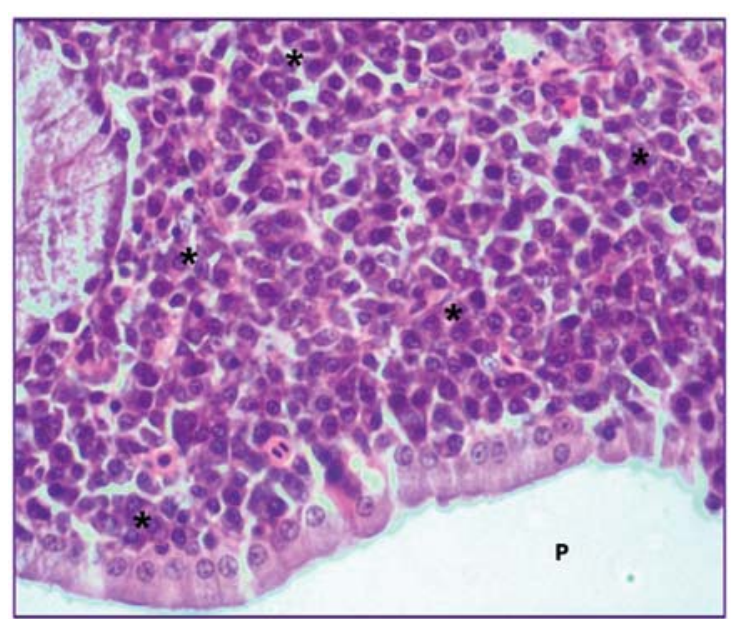

Figure 4. Large number of mature plasma cells $(*)$ infiltrates subepithelial region of the primary duct $(\mathrm{P})$ in 7 month old laying hens. (H\&E 400X)

In all birds older than 3 days plasma cells with Russell bodies are also present. These cells always show a strong PAS positive reaction, so that they can easily be noticed (Fig. 6). The nucleus of plasma cells with Russell bodies is very small, pyknotic and situated eccentrically. The Russell bodies are

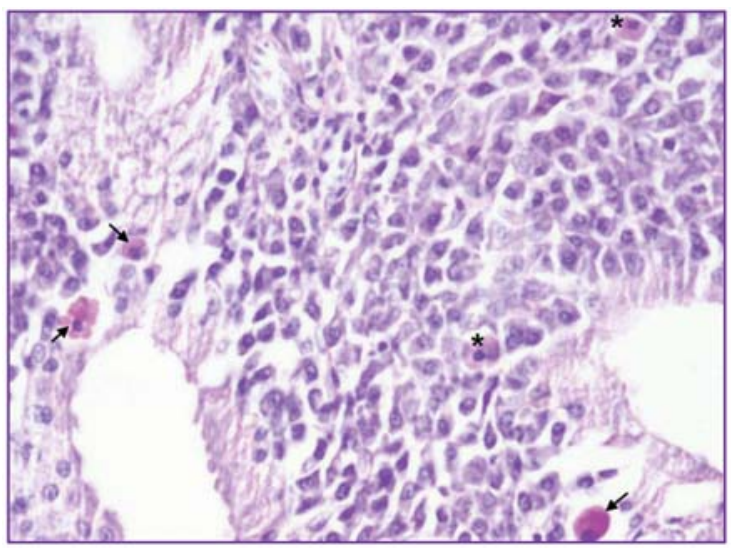

Figure 6. Plasma cells with small, rounded (*) and large, angular $(\rightarrow)$ Russell bodies in 7 month old laying hens. (Periodic acid-Schiff, 400X) 
different in size and shape. In some plasma cells they are very small and rounded, while in others they are quite large and have angular shape. Sporadically, in adult birds the group of lymphod cells is occupied with dense PAS positive material. The cells surrounded by this material are often affected with degenerative changes. Also, this material sometimes protrudes under and between the epithelial cells of glandular ducts.

The correlation coefficient $r^{2}=0,94$ shows that the number of these cells significantly increases $(p<0,05)$ from the time of hatching to the period of 10 months of age (Fig. 7). However, in the period between 4 and 10 months of age this is not a notable growth as it is the case in younger birds. Among numerous plasma cells small groups of lymphocytes and individual heterophils are visible, while the lymphoid nodules are no longer detectable. cells: heterophils, lymphocytes and plasma cells. Although these cells have been previously recorded $(2,4,18,21-23)$, we noticed that their number is directly dependent on bird's ages. In fact, we find that during the lifetime of the laying hens there gradually comes a shift in the dominance of these three cell types. This investigation showed that the gland develops in a similar way as other secondary immune organs.

However, the main morphological characteristic that distinguishes it from others secondary immune organs is the presence of a large number of plasma cells in hens of 4 months of ages and all older birds. This finding indicates that after sexual maturation the Harderian gland in laying hens is mainly responsible for humoral immunity. Additional studies are necessary to confirm this hypothesis. Also, in one of the first research it was assumed

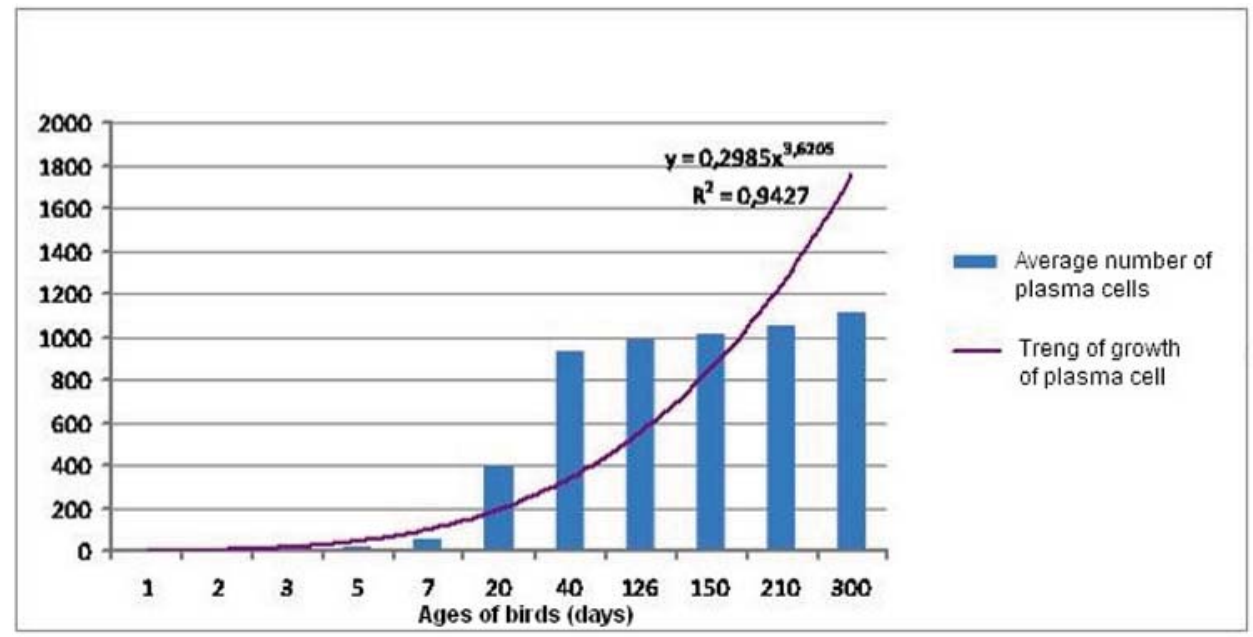

Figure 7. Increasing number of plasma cells from the time of hatching to the period of 10 months of age

\section{DISCUSSION}

Bang and Bang (2) first reported that in the first 7 days after hatching, the interstitium of the Harderian gland is colonised by heterophils, while later with aging, the number of plasma cells progressively increases. Whight et al. $(22,23)$ confirmed these findings and also reported that in adult birds the Harderian gland contains an exceptionally large number of plasma cells. Recently conducted investigations showed that these are $\operatorname{IgA}$, IgM and $\operatorname{IgG}$ containing plasma cells whose number is variable, depending on bird's strain, ages and health $(9,13,14,19-20)$.

Our findings have shown that from the time of hatching to the period of 10 months of age the lymphoid tissue is colonised by three types of 86 that the Harderian gland in chicken is the organ which contains the largest number of plasma cells, probably larger than any other (2). Our histological and statistical findings support this statement. In addition, our statistical results are in agreement with findings obtained by Pawar et al. (15) in White Leghorn and Wight et al. (22) in Shavers hens, indicating similarities between these strains.

Recently conducted research of the Oláh et al. (14) showed that lymphoid tissue of the Harderian gland in domestic fowl histologically can be divided into two major compartments, the head and the body. As previously stated, the head consists of follicle-associated epithelium and subepithelialy situated lymphoid cells and lymphoid nodules. The body is a significantly larger part and it contains 
Developmental changes of lymphoid tissue in the Harderian gland

a large number of plasma cells in different stages of maturation. However, we did not find these histological differences. Our research shows that lymphoid cells are diffusely scattered through the interstitium of the gland, equally in all its parts. Only in 40-days-old chickens we detected the typical lymphoid nodules. Also, opposite to Oláh et al. (14) we found lymphoid nodules in the subepithelial region of the primary duct, through its entire length, from head to the body of the gland. Lymphoid nodules appear just prior to the start of the tissue infiltration with plasma cells, while later they are no longer detectable. Among mature plasma cells we also noticed plasma cells with Russell bodies. These cells were previously recorded by Ohshima and Hiramatsu (13) and Rothwell et al. (17). However, in addition to the previous, we also noticed that Russell bodies come in two different sizes and shapes.

In conclusion, it could be stated that the Harderian gland in laying hens is the largest intraorbital excretory and secondary immune organ. In sexually mature hens, this gland contains an extremely large number of mature plasma cells.

\section{ACKNOWLEDGEMENTS}

We are grateful to the Federal Ministry of Education and Science, Bosnia and Herzegovina which has provided financial support for this research. Also, we are indebted to our colleagues from the Agreks company who have provided all the material for this research.

\section{REFERENCES}

1. Baccari, G.C. (1998). Organogenesis of the Harderian gland: A Comparative survey. Microsc Res Techniq. 34, 6-15.

2. Bang, B., Bang, F.B. (1968). Localized lymphoid tissues and plasma cells in paraocular and paranasal organ systems in chickens. Am J Pathol. 53, 735-751.

3. Boydak, M., Aydin, M.F. (2009). Histology of the Harderian Gland of Domestic Geese (Anser anser domesticus). Acta Vet. Brno 78,199-204.

4. Burns, R.B., Maxwell, M.H. (1979). The structure of the Harderian and lacrimal gland ducts of the Turkey, Fowl and Duck. A light microscope study. J Anat. 128, 285-292.

5. Buzzell, G.R. (1996). The Harderian glandPerspectives. Microsc Res Techniq. 34, 2-5.
6. Chieffi, G., Baccari, G.C., Di Matteo, L., D'istria, M., Minucci, S., Varriale, B. (1996). Cell biology of the Harderian gland. Int Rev Cytol. 168, 1-80.

7. Dimitrov, D.S., Nikifov, I.P. (2005). Histological and Histochemical studies of Harderian gland, lacrimal gland and Bursa of Fabricius in Mulard Ducks (Anas sterilis) with Chlamydial infection. Bulg. J. Vet. Med. 8, 119-127.

8. Hirmatsu, K., Ohshima, K. (2005). Confocal laser scanning microscopy of distribution of Neural Nitric Oxide Synthase (nNOS)-immunoreactive nerves in chicken Harderian gland. J Poult Sci. 42, 24-29.

9. Khan, M.Z.I., Jahan, M.R., Islam, M.N., Haque, Z., Kon, Y. (2007). Immunoglobulin (Ig)-containing plasma cells in the Harderian gland in broiler and native chickens of Bangladesh. Tissue \& Cell 39, 141-149.

10. Maxwell, M.H., Burns, R.B. (1979). The ultrastructure of the epitelium of the ducts of the Harderian glands of turkey, fowl and duck. J Anat. 128, 445-459.

11. Maxwell, M.H., Rothwell, B., Burns, R.B. (1986). A fine structural study of the turkey Harderian gland. J Anat. 148, 147-157.

12. Mobini, B. (2012). Histological and histochemical studies on the Harderian gland in native chickens. Veterinarni Medicina 57, 404-409.

13. Ohshima, K., Hiramatsu, K. (2002). Immunohistochemical localisation of three different immunoglobulin classes in the Harderian gland of young chickens. Tissue \& Cell 34, 129-133.

14. Oláh, I., Kupper, A., Kittner, Z. (1995). The lymphoid substance of the chicken's Harderian gland is organized in two histologically distinct compartments. Microsc Res Techniq. 34, 166-176.

15. Pawar, A., Venkatkrishnan, A., Vijayeravagan, C., Ramkrishnn, V. (1998). Histological study of the Harderian gland of White Leghorn with reference to plasma cells. Indian J Anim Sci. 68, 141-142.

16. Payne, A.P. (1994). The Harderian gland: A Tercentennial Review. J Anat185, 1-49.

17. Rothwell, B., Wight, P.A.L., Burns, R.B., Mackenzie, G.M. (1972). The Harderian glands of domestic Fowl. III. Ultrastructure. J Anat. 112, 233-250

18. Schramm, U. (1980). Lymphoid cells in the Harderian gland of birds. An electron microscopical study. Cell Tissue Res. 205, 85-94. 
19. Scott, T.R., Savage, M.L. (1996). Immune cell proliferation in the Harderian gland: An avian model. Microsc Res Techiq. 34,149-5

20. Scott, T.R., Savage, M.L., Olah, I. (1993). Plasma cells of the chicken Harderian gland. Poult Sci. 72, $1273-1279$.

21. Shirama, K., Satoh, T., Kitamura, T., Yamada, J. (1996). The avian Harderian gland: morphology and immunology. Microsc Res Techniq. 34, 16-27.
22. Wight, P.A.L, Burns, R.B., Rothwell, B., Mackenzie, G.M. (1971a). The Harderian glands of domestic Fowl. I. Histology, with references to the genesis of plasma cells and Russell bodies. J Anat. 110, 307-315.

23. Wight, P.A.L, Mackenzie, G.M., Rothwell, B., Burns, R.B. (1971b). The Harderian glands of domestic Fowl. II. Histochemistry. J Anat. 110, 323-333.

Please cite this article: Pamela Bejdić, Rizah Avdić, Ljiljana Amidžić, Velida Ćutahija, Faruk Tandir, Nedžad Hadžiomerović Developmental changes of lymphoid tissue in Harderian gland of the laying hens. Mac Vet Rev 2014; 37 (1): 83-88. http://dx.doi.org/10.14432/j.macvetrev.2014.02.009 